\title{
Penerapaan Sistem Informasi Desa Menggunakan OpenSID di Desa Tanjung Dayang Selatan, Kabupaten Ogan Ilir, Sumatera Selatan
}

\author{
Abdiansah*1, Alvi Syahrini Utami², Novi Yusliani ${ }^{3}$, Kanda Januar Miraswan ${ }^{4}$, Ahmad Fali Oklilas ${ }^{5}$ \\ 1,2,3,4Jurusan Teknik Informatika, Fakultas Ilmu Komputer, Universitas Sriwijaya \\ 5 Jurusan Sistem Komputer, Fakultas Ilmu Komputer, Universitas Sriwijaya \\ *e-mail: abdiansah@unsri.ac.id ${ }^{1}$,alvisyahrini@ilkom.unsri.ac.id ${ }^{2}$,novi_yusliani@unsri.ac.id³ \\ kandajm@ilkom.unsri.ac.id ${ }^{4}$,fali@ilkom.unsri.ac.id ${ }^{5}$
}

\begin{abstract}
The Village Information System (SID) is a set of tools and processes for utilizing data and information to support community-based resource management at the village level. SID is part of the implementation of the Village Law (UU). Village Law Article 86 Law no. 6/2014 concerning Information Systems for Village Development and Rural Area Development. The village has not been able to implement SID due to a lack of understanding by village officials about SID. Therefore, the need for SID training is very urgent for villages, especially village officials. To solve this problem, the Faculty of Computer Science, Sriwijaya University, conducted an OpenSID-based SID training activity through the Community Service (PkM) program. The results of the training showed that the material provided was quite understood by all training participants even though they had never used a similar application. In addition, they believe that SID can assist village administration and improve village information services.
\end{abstract}

Keywords: SID, OpenSID, PKM, Pengabdian, Masyarakat

\begin{abstract}
Abstrak
Sistem Informasi Desa (SID) adalah seperangkat alat dan proses pemanfaatan data dan informasi untuk mendukung pengelolaan sumber daya berbasis komunitas di tingkat Desa. SID merupakan bagian dari implementasi Undang-Undang (UU) Desa. UU Desa Pasal 86 UU no. 6 Tahun 2014 tentang Sistem Informasi Pembangunan Desa dan Pembangunan Kawasan PerDesaan. Desa belum dapat mengimplementasikan SID karena kurangnya pemahaman perangkat Desa tentang SID. Oleh karena itu, kebutuhan akan pelatihan SID menjadi sangat urgen bagi Desa khususnya para perangkat Desa. Untuk mengatasi masalah tersebut, Fakultas Ilmu Komputer, Universitas Sriwijaya, melakukan kegiatan pelatihan SID berbasis OpenSID melalui program Pengabdian Kepada Masyarakat (PkM). Hasil dari pelatihan diperoleh bahwa materi yang diberikan cukup dipahami oleh semua peserta pelatihan meskipun mereka belum pernah menggunakan aplikasi yang sejenis. Selain itu, mereka percaya bahwa SID dapat membantu administrasi Desa dan meningkatkan layanan informasi Desa.
\end{abstract}

Kata kunci: SID, OpenSID, PkM

\section{PENDAHULUAN}

Desa Tanjung Dayang Selatan, Kecamatan Indralaya Selatan, Kecamatan Indralaya Selatan, berjarak sekitar $32 \mathrm{Km}$ dari pusat kota Kabupaten Ogan Ilir, Sumatera Selatan. Hampir sebagian besar penduduknya berprofesi sebagai karet (sekitar 90\%), sebagian kecil sebagai pedagang/wiraswasta, karyawan swasta dan pegawai negeri sipil. Lokasi Desa yang berada tidak terlalu jauh dari pusat kota memungkinkan dinamika masyarakat yang cukup tinggi. Informasi Desa yang terbaru dan pelayanan administrasi kependudukan yang cepat dan akurat menjadi kebutuhan penting masyarakat. Kondisi saat ini, pelayanan administrasi masih kurang maksimal, pengurusan administrasi masih membutuhkan waktu yang lama. Meskipun beberapa perangkat Desa memiliki kemampuan TI (Teknologi Informasi) sederhana tetapi proses administrasi masih dilakukan secara manual. Untuk meningkatkan mutu layanan informasi di Desa maka diperlukan sistem informasi berbasis komputer yang bisa menyajikan data lebih akurat serta dapat menyelesaikan urusan administrasi lebih cepat.

Sistem Informasi Desa (SID) adalah seperangkat alat dan proses pemanfaatan data dan informasi untuk mendukung pengelolaan sumber daya berbasis komunitas di tingkat Desa. SID sudah banyak diterapkan pada Desa (Erbito dan Hapsari, 2019; Hadi dkk., 2019; Laome dkk., 
2019). Setidaknya ada dua hal yang menjadikan kehadiran SID menjadi penting. Pertama, keinginan untuk mewujudkan partisipasi, transparansi dan akuntabilitas pemerintahan Desa, yang berarti bahwa SID selain sebagai perangkat pemroses informasi juga menjadi perangkat demokrasi. Kedua, banyaknya data Desa yang berserakan dan tidak terkumpul secara rapi di arsip pemerintahan Desa yang berarti bahwa SID merupakan perangkat teknokratis yang membuat penyelenggaraan pemerintahan Desa menjadi lebih efisien dan efektif (Jahja dkk., 2012). SID merupakan bagian dari implementasi Undang-Undang (UU) Desa. UU Desa Pasal 86 UU no. 6 Tahun 2014 tentang Sistem Informasi Pembangunan Desa dan Pembangunan Kawasan PerDesaan menyebutkan bahwa Desa berhak mendapatkan akses informasi melalui sistem informasi yang dikembangkan oleh Pemerintah Daerah Kabupaten atau Kota.

Untuk mendukung pengelolaan dan pemanfaaatan data Desa yang diatur dalam bagian ketiga UU Desa Pasal 86, pemerintah memberikan platform tata kelola Desa yang bernama SiDeKa (https://sideka.id) yaitu seperangkat alat meliputi fasilitas perangkat keras dan perangkat lunak, infrastruktur jaringan, serta sumber daya manusia yang dikelola oleh Pemerintah Desa. SiDeKa sudah digunakan sebanyak 6.536 Desa di seluruh Indonesia (Fikri dkk., 2020). Meskipun demikian, pada praktiknya masih banyak Desa yang belum menjalankan karena keterbatasan oleh berbagai faktor, salah satunya adalah kurangnya sumber daya manusia yang paham tentang sistem informasi Desa. Selain itu terdapat pula faktor teknis terkait dengan SiDeKa seperti proses adminstrasi yang cukup panjang, fitur yang kurang, dukungan komunitas dan informasi yang masih sedikit, dan lainnya. Salah satu sistem informasi alternatif selain SiDeKa adalah OpenSID yang berbasis open source (sumber terbuka) dengan dukungan komunitas yang besar.

OpenSID (https://github.com/OpenSID/OpenSID) adalah Sistem Informasi Desa (SID) yang dibuat secara terbuka dan dapat dikembangkan bersama-sama oleh komunitas peduli SID. Beberapa Desa sudah menerapkan OpenSID (Jalma dkk., 2019; Karouw dkk., 2019; Pagiling dkk., 2019, Sandy dkk., 2020). Selain untuk menyimpan data penduduk, OpenSID juga bisa digunakan untuk web Desa sebagai media promosi dan penyebaran informasi Desa (Rahim dkk., 2019; Setiaji dkk., 2019). Selain itu, OpenSID juga dapat diintegrasikan dengan aplikasi lain seperti smsgateway (Wijanarko, 2019), monitoring detak jantung warga (Yuhefizar dkk., 2019), dan penilaian kepuasan pengguna (Widodo dkk., 2019). Ada tiga tujuan pengembangan OpenSID, yaitu: (1) Memudahkan pengguna untuk mendapatkan SID secara bebas, tanpa proses birokrasi; (2) Memudahkan pengguna menyerap rilis SID terbaru; dan (3) Memungkinkan pegiat SID untuk membuat kontribusi langsung pada kode sumber aplikasi SID. OpenSID diharapkan dapat membantu pemerintah Desa dalam beberapa hal berikut: kantor Desa lebih efisien dan efektif, pemerintah Desa lebih transparan dan akuntabel, layanan publik lebih baik, dan warga mendapat akses lebih baik pada informasi Desa. OpenSID sudah digunakan sebanyak 6.092 Desa dengan rincian 3.513 Desa sudah online, dan 4.175 masih offline (Fikri dkk., 2020). Berdasarkan info tersebut, total penggunaan SID (SiDeKa dan OpenSID) sebanyak 12.628 dari 74.957 Desa seluruh Indonesia, jadi masih ada sekitar 83,15\% Desa yang belum mempunyai SID. Gambar 1 menampilkan perbandingan jumlah Desa pengguna SID berdasarkan data dari Fikri dkk. (Fikri dkk., 2020).

\section{METODE}

Metode pelaksanaan kegiatan dapat dilihat pada Gambar 1. Secara garis besar ada empat tahapan yang dilakukan, yaitu: tahap Persiapan, tahap pemasangan SID dan Web Desa, tahap pelatihan SID dan Web Desa, tahap peluncuran SID dan Web Desa, dan Evaluasi Kegiatan. Tahap persiapan merupakan tahap awal kegiatan. Ada beberapa hal yang dilakukan antara lain: melakukan survei tempat lokasi pengabdian masyarakat, menyiapkan sarana \& prasarana kegiatan seperti ATK dan lainnya, menyiapkan materi kegiatan, seperti pembuatan modul, menyiapkan peralatan dan bahan untuk membuat SID dan Web Desa, menyiapkan lokasi pemasangan SID dan Web Desa, menyiapkan tempat lokasi pelatihan, dan menyiapkan fasilitas pendukung kegiatan lainnya. 
Pada tahap pemasangan SID dan web Desa ada dua kegiatan yang dilakukan, yaitu: (1) Pemasangan Sistem Informasi Desa (SID), dan (2) Pemasangan Web Desa. Kedua pemasangan tersebut meliputi pemasangan perangkat keras dan perangkat lunak. Pemasangan SID dan Web Desa dilakukan oleh teknisi yang dibantu oleh perangkat Desa. Komputer yang dijadikan sebagai tempat percobaan SID dan Web Desa sementara masih menggunakan komputer dari tim pengabdian dan komputer dari Desa. Pemasangan tersebut akan dilakukan oleh teknisi yang langsung datang ke lokasi Desa. Status SID dan Web Desa yang dipasang masih bersifat offline. Pemasangan secara online akan dilakukan pada tahap peluncuran SID dan Web Desa, setelah melakukan pelatihan dan pendampingan.

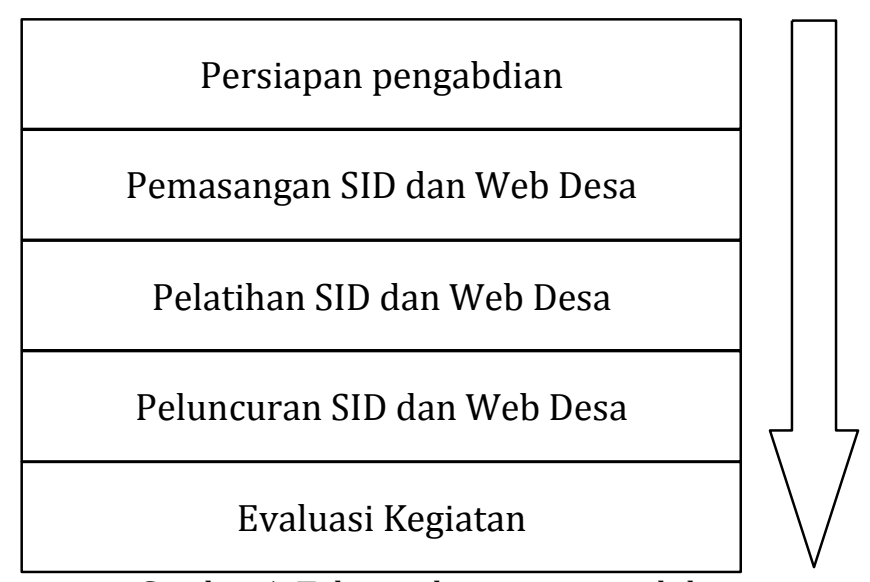

Gambar 1. Tahapan kegiatan pengabdian

Pada tahap pelatihan SID dan Web Desa berfokus pada penggunaan seluruh fitur-fitur OpenSID dan menu administrasi untuk Web Desa. Lokasi pelatihan direncanakan akan dilaksanakan di Laboratorium Komputer, Fakultas Ilmu Komputer, Universitas Sriwijaya. Mengingat, sarana dan prasarana belum bisa dilakukan di lokasi Desa karena belum memadai. Kegiatan pelatihan akan mengikuti aturan pemerintah terkait dengan prosedur pencegahan COVID-19. Pada tahap peluncuran SID dan Web Desa ada dua kegiatan yang dilakukan, yaitu: (1) Pemberian seperangkat komputer yang sudah terpasang SID dan alat bantu lainnya dari tim pengabdian ke Desa, dan (2) Pemasangan Web Desa di Internet dengan membeli hosting dan domain Desa. Tahap ini merupakan tahap akhir dari kegiatan pengabdian yang memberikan luaran hasil kegiatan berupa SID dan Web Desa. Terakhir adalah tahap evaluasi kegiatan. Tujuan tahap ini adalah untuk mengevaluasi proses selama pengabdian dan apakah luaran hasil kegiatan sudah tepat sasaran, salah satunya adalah menganalisis hasil survei yang diberikan setelah pelatihan selesai.

\section{HASIL DAN PEMBAHASAN}

\subsection{Pelaksanaan Kegiatan}

Kegiatan pengabdian kepada masyarakat dilaksanakan dengan bekerjasama dengan Desa Tanjung Dayang Selatan, Kecamatan Indralaya Selatan, Kabupaten Ogan Ilir, Sumatera Selatan. Pelaksanaan kegiatan dilakukan melalui beberapa tahapan yang saling berkaitan untuk kelancaran kegiatan. Acara kegiatan pengabdian dilaksanakan pada tanggal 25 November 2020, dari pukul 07:00-16:00. Peserta kegiatan adalah para perangkat Desa. Lokasi kegiatan bertempat di Laboratorium Sistem Informasi dan Rekayasa Perangkat Lunak, Gedung A, Lantai 1, Fakultas Ilmu Komputer, Universitas Sriwijaya. Kegiatan pengabdian mendapatkan respon yang positif dari peserta yang datang lebih awal dan semangat berdiskusi terkait dengan sistem informasi Desa. Kegiatan pengabdian ini dibagi menjadi enam sesi, yaitu: (1) Pembukaan acara oleh ketua pelaksana; (2) Pengantar Sistem Informasi Desa (SID) dengan menonton video tentang Desa-Desa yang menggunakan SID berbasis OpenSID; (3) Pelatihan pengantar SID dilanjutkan dengan entri 
data penduduk menggunakan OpenSID; (4) Pelatihan konfigurasi web Desa; (5) Penyerahan hibah PKM berupa seperangkat komputer desktop (PC dan UPS) kepada perwakilan Desa; dan (6) Penutupan oleh ketua pelaksana.

\subsection{Hasil Kegiatan}

Sesi pertama adalah pembukaan acara yang dilakukan oleh ketua pelaksana. Peserta diberikan informasi tentang tujuan kegiatan pengabdian yaitu pelatihan sistem informasi Desa yang berfokus pada entri data dan konfigurasi web Desa. OpenSID memberikan banyak fitur sehingga tidak cukup diselesaikan dengan pelatihan sehari. Oleh karena itu, kegiatan ini berfokus pada dua masalah yang penting bagi Desa yaitu entri data dan web Desa. Setelah itu ketua pelaksana memberikan komputer hibah kepada peserta perwakilan Desa seperti yang dapat dilihat pada Gambar 2. Komputer hibah tersebut sudah dipasang aplikasi OpenSID sehingga perangkat Desa dapat langsung mengoperasikan OpenSID setelah pelatihan berakhir. Tim pengabdian membuat modul pelatihan aplikasi OpenSID versi 20.11 yang disusun sendiri berdasarkan percobaan menggunakan aplikasi OpenSID versi 20.11. Pembaharuan aplikasi OpenSID cukup cepat, yaitu setiap sebulan sekali. Oleh karena itu, modul yang dibuat disesuaikan dengan versi aplikasi OpenSID yang digunakan. Modul tersebut berisi 66 halaman yang memuat materi entri data penduduk dan konfigurasi web Desa, setiap peserta diberikan modul pelatihan OpenSID.

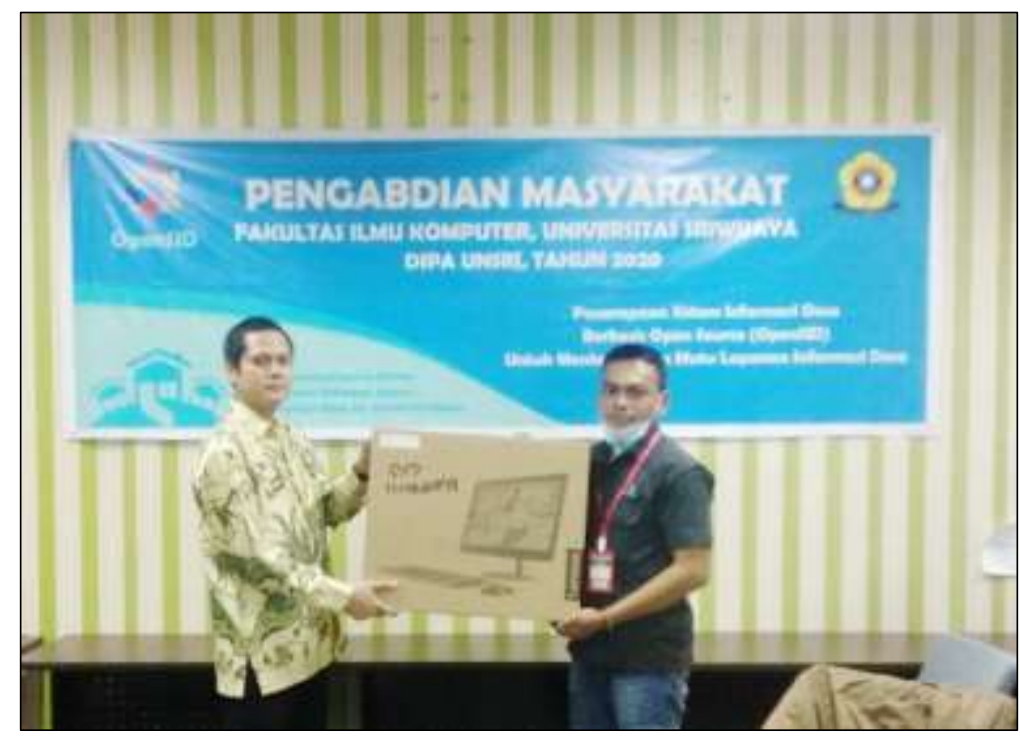

Gambar 2. Pemberian hibah komputer kepada perwakilan Desa

Sebelum masuk ke sesi entri data penduduk Desa, peserta terlebih dahulu diberikan pengantar tentang aplikasi OpenSID dan cara membuka/menjalankan OpenSID. Komputer praktik untuk peserta sudah terpasang aplikasi OpenSID versi 20.11. Tahap pertama adalah pengisian informasi Desa setelah itu baru dilanjutkan ke pengisian data penduduk. Selain itu, peserta juga diperkenalkan dan diajarkan juga cara membuat surat otomatis dan mengedit format surat. Terakhir, adalah pengenalan tentang fitur statistik penduduk yang dapat menampilkan informasi berdasarkan data-data penduduk yang tersimpan. Sesi selanjutnya adalah konfigurasi web Desa. Tim pengabdian telah memberikan sewa domain dan hosting untuk web Desa selama 1 tahun. Jika habis masa berlaku, Desa harus membayar sewa tahun berikutnya. Web Desa untuk Desa Tanjung Dayang Selatan dapat diakses di www.tanjungdayangselatan.com. Suasana kegiatan pelatihan dapat dilihat pada Gambar 3. Pada gambar tampak bahwa setiap peserta diberikan pendamping (mahasiswa) untuk memantau dan memberikan bantuan jika ada peserta yang kesulitan dalam memahami modul pelatihan. 


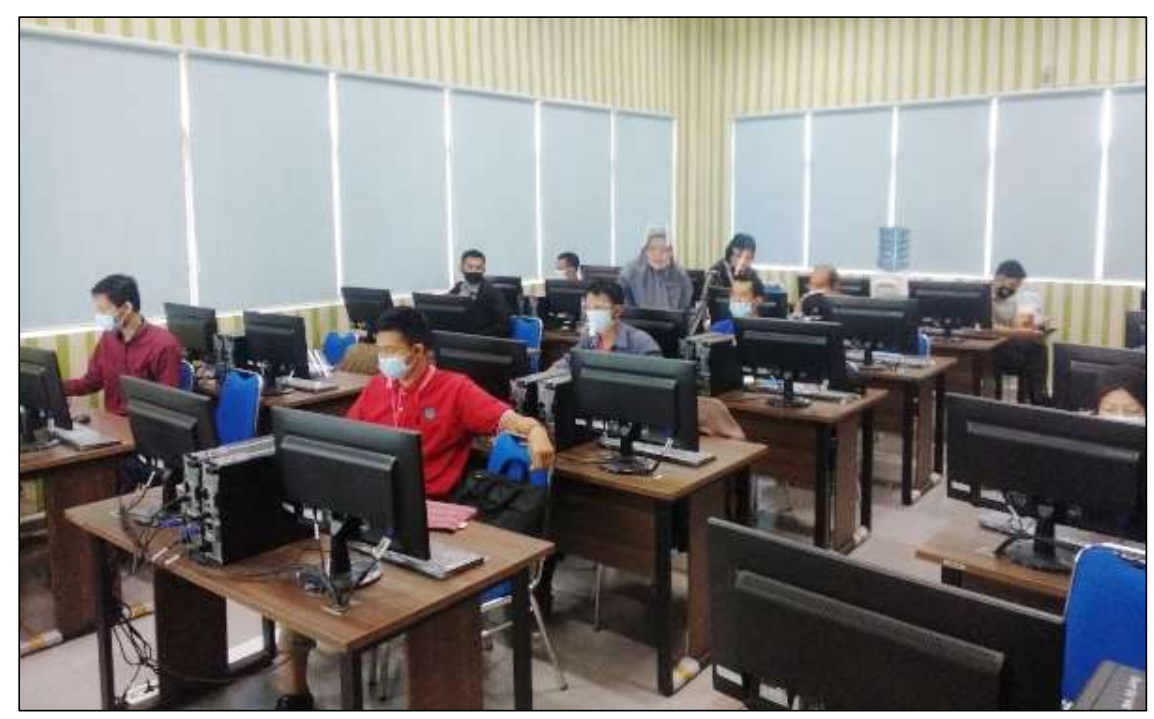

Gambar 3. Suasana pelatihan sistem informasi Desa

Selanjutnya, tampilan web Desa dapat dilihat pada Gambar 4. Pelatihan konfigurasi web Desa dilakukan secara lokal (offline) tetapi peserta diberikan akses untuk melakukan konfigurasi secara online. Meskipun aplikasi OpenSID bisa untuk menyimpan data penduduk secara online di server, tetapi tim pengabdian tidak menyarankannya karena terkait dengan keamanan server yang belum terjamin. Oleh karena itu, web Desa hanya digunakan sebagai sarana untuk menyebarkan informasi dan promosi Desa. Sedangkan untuk data kependudukan tetap disimpan secara offline.

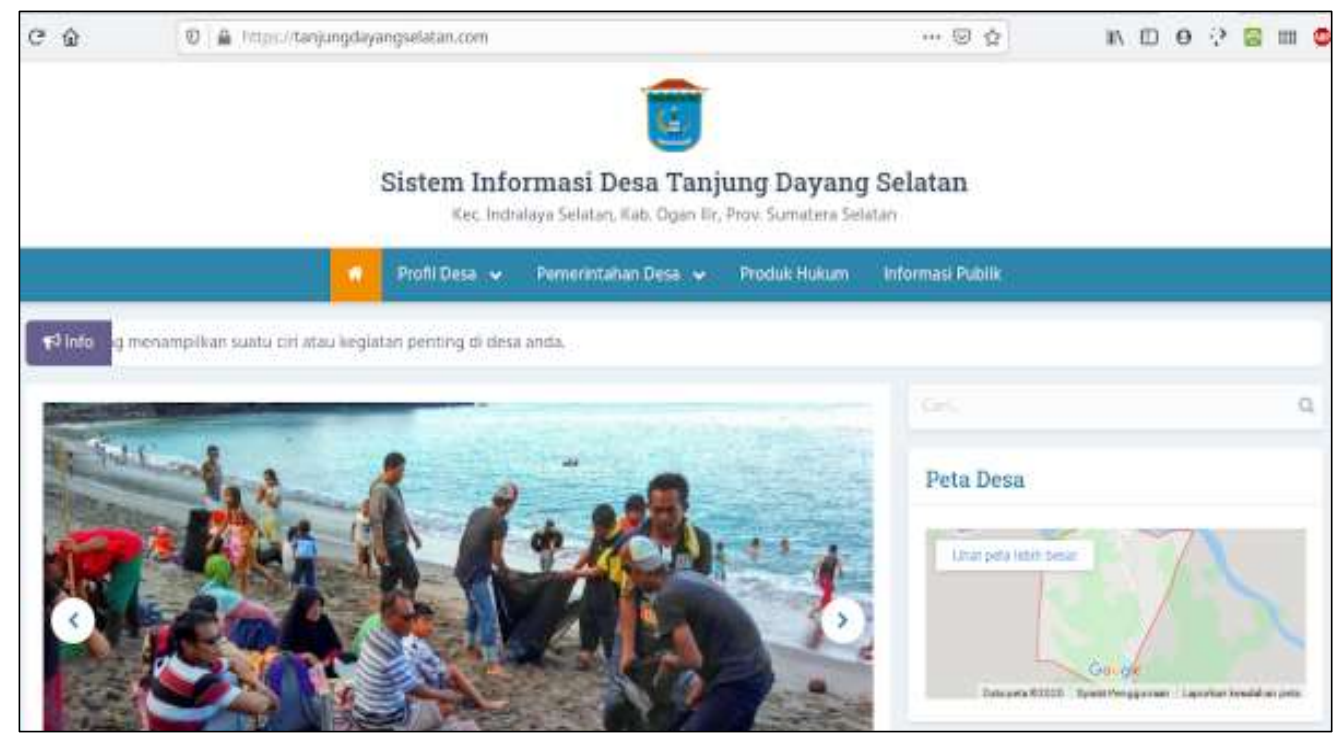

Gambar 4. Web Desa yang sudah berjalan secara online

Kegiatan terakhir peserta setelah pelatihan adalah mengisi form survei yang diberikan oleh tim pengabdian. Survei tersebut berisi 10 pertanyaan dasar terkait dengan proses pelatihan. Pada Tabel 1 berisi pertanyaan-pertanyaan yang diberikan saat melakukan survei. Kesepuluh pertanyaan tersebut dibagi menjadi beberapa topik, antara lain tentang pemahaman materi pelatihan, kesan penggunaan aplikasi OpenSID, kemampuan praktik entri data penduduk, pembuatan surat, dan konfigurasi web, serta harapan setelah menggunakan aplikasi OpenSID. 
Tabel 1. Pertanyaan survei

\begin{tabular}{cl}
\hline No. & \multicolumn{1}{c}{ Pertanyaan } \\
\hline 1 & Apakah materi pelatihan mudah dipahami? \\
2 & Apakah aplikasi OpenSID cukup mudah digunakan? \\
3 & Apakah pernah menggunakan aplikasi yang sejenis dengan OpenSID? \\
4 & Apakah ada kesulitan saat praktik entri data penduduk Desa? \\
5 & Apakah ada kesulitan saat praktik pembuatan surat? \\
6 & Apakah ada kesulitan saat praktik mengatur tampilan web? \\
7 & Apakah ada kesulitan saat praktik membuat artikel web? \\
8 & Apakah nanti bisa belajar menggunakan aplikasi OpenSID secara mandiri? \\
9 & Apakah aplikasi OpenSID nanti bisa membantu administrasi Desa? \\
10 & Apakah aplikasi OpenSID nanti bisa meningkatkan layanan informasi Desa? \\
\hline
\end{tabular}

\subsection{Evaluasi Kegiatan}

Evaluasi kegiatan pada pengabdian meliputi evaluasi proses pelaksanaan pelatihan dan hasil survei yang diberikan. Pada proses pelaksanaan pelatihan, terdapat beberapa peserta yang cukup serius dan beberapa peserta yang kurang semangat karena mungkin belum terlalu familiar menggunakan komputer. Selain itu, komposisi usia peserta berdasarkan pengamatan langsung juga beragam dari yang dewasa sampai cukup tua (kami tidak mendata umur). Hasil evaluasi berdasarkan pengamatan di lapangan menunjukkan bahwa usia peserta yang cukup tua yang menunjukkan kurang semangat, sisanya cukup memuaskan. Ada beberapa peserta yang sangat antusias belajar dan bertanya kepada instruktur. Selanjutnya hasil survei dapat dilihat pada Gambar 5. Survei dilakukan kepada para peserta yang berjumlah 10 orang dengan memberikan pertanyaan yang ada di Tabel 1 menggunakan skala rating: Ya, Sedang, dan Tidak. Untuk pertanyaan 1-3 pada Tabel 1 diperoleh informasi bahwa terdapat $80 \%$ peserta yang dapat memahami materi pelatihan, dan $70 \%$ bisa menggunakan aplikasi OpenSID meskipun semua peserta (100\%) belum pernah menggunakan aplikasi yang mirip dengan OpenSID.

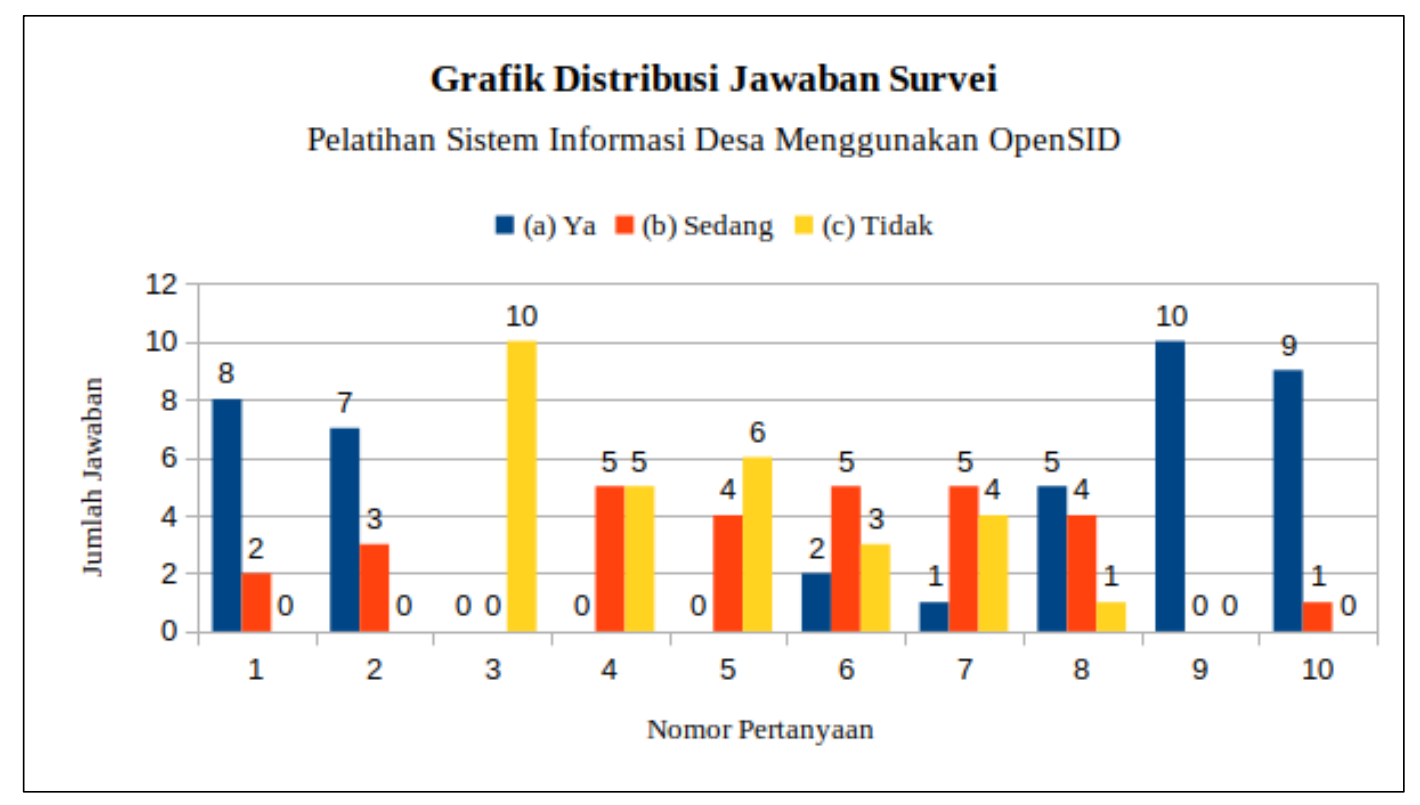

Gambar 5. Grafik distribusi jawaban survei 
Pada pemahaman praktik kegiatan entri data penduduk dan pembuatan surat (pertanyaan $4 \mathrm{~s} / \mathrm{d}$ 5) diperoleh informasi bahwa tidak terdapat kendala berarti meskipun ratarata persentase tidak terdapat kesulitan sekitar 55\%, sisanya agak kesulitan sekitar $45 \%$. Ini berarti bahwa mayoritas peserta dapat melakukan praktik entri data penduduk dan pembuatan surat. Selanjutnya, pada praktik konfigurasi web Desa (pertanyaan $6 \mathrm{~s} / \mathrm{d}$ 7) diperoleh informasi bahwa sebanyak 35\% yang mengalami kesulitan, 50\% agak kesulitan, dan 35\% tidak ada kesulitan. Ini berarti bahwa mayoritas peserta cukup kesulitan saat melakukan praktik konfigurasi web Desa. Informasi ini berguna untuk perbaikan selanjutnya.

Aplikasi OpenSID memberikan fitur-fitur yang cukup banyak selain dari yang diberikan di pelatihan, sehingga pelatihan yang hanya sehari belum bisa memberikan hasil yang komprehensif. Oleh karena itu, diberikan pertanyaan pada survei apakah peserta dapat atau sanggup belajar aplikasi OpenSID secara mandiri (pertanyaan 8). Hasil yang diperoleh adalah sekitar 50\% peserta yang merasa bisa belajar mandiri, 40\% yang agak bisa, dan $10 \%$ (1 orang) yang tidak bisa. Ini berarti bahwa separuh peserta cukup yakin bisa belajar aplikasi OpenSID secara mandiri. Terakhir adalah pertanyaan tentang manfaat aplikasi OpenSID (pertanyaan 9 dan 10), hampir 95\% peserta memberikan jawaban ya, ini berarti aplikasi OpenSID dapat bermanfaat dan meningkatkan layanan informasi Desa.

\section{KESIMPULAN}

Kegiatan telah berjalan dengan baik dan lancar dengan dihadiri oleh peserta perangkat Desa Tanjung Dayang Selatan, Kecamatan Indralaya Selatan, Kabupaen Ogan Ilir, Sumatera Selatan. Berdasarkan hasil survei diperoleh informasi bahwa meskipun semua peserta belum pernah menggunakan aplikasi sistem informasi Desa yang mirip dengan OpenSID tetapi hampir mayoritas dari peserta mampu memahami materi pelatihan. Hal ini menunjukkan bahwa materi pelatihan yang dibuat sudah cukup baik. Hal positif lainnya adalah peserta cukup menguasai praktik entri data penduduk dan pembuatan surat, hal ini cukup penting mengingat unsur utama dari sistem informasi Desa adalah data penduduk. Sedangkan untuk konfigurasi Desa terdapat kesulitan, karena terlalu banyak menu yang dioperasikan. Terakhir, peserta dapat merasakan bahwa aplikasi OpenSID dapat membantu administrasi Desa dan meningkatkan layanan informasi Desa.

Sistem Informasi Desa berbasis OpenSID terus berkembang seiring dengan pembaharuan setiap bulan oleh para kontributor. Pembaharuan tersebut berdasarkan permintaan fitur baru oleh komunitas pengguna. Pihak OpenSID memberlakukan "OpenSID Premium" bagi pengguna yang memberikan donasi untuk menggunakan fitur baru, setelah dalam jangka waktu tertentu fitur baru tersebut akan digratiskan. Untuk mempermudah penggunaan aplikasi OpenSID, sebaiknya Desa dapat mengalokasikan dana untuk "OpenSID Premium" karena banyak sekali keuntungannya, selain ada dukungan teknis juga ada layanan keamanan data.

\section{UCAPAN TERIMA KASIH}

Terima kasih kepada Universitas Sriwijaya atas dukungan dana dalam kegiatan ini yang dibiayai oleh Dana PNBP Universitas Sriwijaya Sesuai dengan Surat Perjanjian Penugasan Tenaga Pelaksana Pengabdian kepada Masyarakat Skema Aplikasi IPTEK dan Pengembangan Seni Budaya Lokal Nomor: 0018.041/UN9/SB3.LP2M.PM/2020.

\section{DAFTAR PUSTAKA}

Erbito, Y. E. (2019). Konsep Pengelolaan Administrasi Menggunakan Sistem Informasi Desa Pada Desa Sebente Kabupaten Bengkayang. Business, Economics and Entrepreneurship, 1(2), 37 42. 
Fikri, R. (2019). Village Vs Technology: Critical Discourse Analysis Of Technology-Based Villages Government System In Bengkalis Regency, Riau Province. Prosiding Icogiss 2019, 445-454.

Hadi, A. P., Indiyarti, D., \& Miharja, D. L. (2019). Proses Difusi Inovasi Dan Keputusan Inovasi Sistem Informasi Desa: Studi Kasus Di Kabupaten Lombok Timur. Indonesian Journal of Socio Economics, 1(1), 1-11.

Jahja, R., Hartaya, Dina Mariana, Meldi Rendra. (2012). Sistem Informsi Desa Sistem Informasi dan Data untuk Pembaruan Desa. Jogjakarta: Combine Resource Institution

Jalma, H., Putera, R. E., \& Kusdarini, K. (2019). E-Government dengan Pemanfaatan Web OpenSID dalam Pelayanan Publik di Nagari Tanjung Haro Sikabu-kabu Padang Panjang. Publik (Jurnal Ilmu Administrasi), 8(1), 24-37.

Karouw, S., Narasiang, B., \& Litouw, J. (2019). Analisis Pengukuran Model Penerimaan Teknologi OpenSID di Area Rural dan Urban. CogITo Smart Journal, 5(2), 191-202.

Laome, L., Variani, V. I., Mukhsar, M., \& Tenriawaru, A. (2019). Perancangan dan Pengelolaan Sistem Informasi Desa (SID) Bagi Aparat Desa Puasana Kecamatan Moramo Utara Kabupaten Konawe Selatan. Jurnal Pengabdian Masyarakat Ilmu Terapan (JPMIT), 1(1).

Pagiling, L., Nur, M. N. A., Galugu, I., \& Lolok, A. (2019). Optimalisasi Sistem Pembuatan Surat Pelayanan Masyarakat Desa berbasis Online Di Kabupaten Konawe Selatan menggunakan OpenSID. Jurnal Pengabdian Masyarakat Ilmu Terapan (JPMIT), 1(1).

Rahim, A. R., Syufa'atus, S., \& Triska, P. L. (2019). Pembuatan Web Desa Karanggeneng Sebagai Sarana Informasi Desa Dan Promosi Desa. DedikasiMU (Journal of Community Service), 1(1), 35-42.

Setiaji, P., Pradipta, L. M., \& Utomo, A. B. (2019). Web-Based Village Information System in Dalegan Village-Panceng District-Gresik Regency. Kontribusia (Research Dissemination for Community Development), 2(2), 39-41.

Wijanarko, A. (2019). Integrasi Data SID dan SMS Gateway menggunakan Web Service untuk Layanan Desa Blank Spot Area Data. Jurnal Teknik Informatika dan Sistem Informasi, 5(2).

Yuhefizar, Y., Nasution, A., Putra, R., Asri, E., \& Satria, D. (2019). Alat Monitoring Detak Jantung Untuk Pasien Beresiko Berbasis IoT Memanfaatkan Aplikasi OpenSID berbasis Web. Jurnal RESTI (Rekayasa Sistem dan Teknologi Informasi), 3(2), 265-270.

Sandy, B. D. A., Hisyam, E. S., Apriyanti, Y., Gunawan, I., \& Radiyan, M. F. (2020). Pelatihan Aplikasi Data Kependudukan dan Surat Menyurat di Desa Jada Bahrin. Dinamisia: Jurnal Pengabdian Kepada Masyarakat, 4(1), 106-112.

Widodo, W., Dahlia, A. S., \& Ardiansyah, D. (2020). Pengaruh Kemudahan Penggunaan, Kualitas Informasi, Kualitas Interaksi, Terhadap Kepuasan Pengguna Aplikasi Open Source Menggunakan Webqual. JIKO (Jurnal Informatika dan Komputer), 3(2), 81-86. 